Marquette University

e-Publications@Marquette

Chemistry Faculty Research and Publications

Chemistry, Department of

$12-18-2008$

\title{
Resonance Raman Characterization of the Peroxo and Hydroperoxo Intermediates in Cytochrome P450
}

Ilia G. Denisov

University of Illinois at Urbana-Champaign

Piotr J. Mak

Marquette University, piotr.mak@marquette.edu

Thomas M. Makris

University of Illinois at Urbana-Champaign

Stephen G. Sligar

University of Illinois at Urbana-Champaign

James R. Kincaid

Marquette University, james.kincaid@marquette.edu

Accepted version. Journal of Physical Chemistry A, Vol. 112, No. 50 (December 18, 2008):

13172-13179. DOI. (C) 2008 American Chemical Society. Used with permission. 


\title{
Resonance Raman Characterization of the Peroxo and Hydroperoxo Intermediates in Cytochrome $\mathrm{P}_{45} \mathrm{O}^{+}$
}

\author{
Ilia G. Denisov \\ Department of Biochemistry, University of Illinois, \\ Urbana, IL \\ Piotr J. Mak \\ Department of Chemistry, Marquette University, \\ Milwaukee, WI \\ Thomas M. Makris \\ Department of Biochemistry, University of Illinois, \\ Urbana, IL \\ Stephen G. Sligar \\ Department of Biochemistry, Department Chemistry, \\ College of Medicine, University of Illinois, \\ Urbana, IL \\ James R. Kincaid \\ Department of Chemistry, Marquette University, \\ Milwaukee, WI
}




\begin{abstract}
Resonance Raman (RR) studies of intermediates generated by cryoreduction of the oxyferrous complex of the D251N mutant of cytochrome $\mathrm{P}^{4} 50_{\text {cam }}$ (CYP101) are reported. Owing to the fact that proton delivery to the active site is hindered in this mutant, the unprotonated peroxo-ferric intermediate is observed as the primary species after radiolytic reduction of the oxy-complex in frozen solutions at $77 \mathrm{~K}$. In as much as previous EPR and ENDOR studies have shown that annealing of this species to $\sim 180 \mathrm{~K}$ results in protonation of the distal oxygen atom to form the hydroperoxo intermediate, this system has been exploited to permit direct RR interrogation of the changes in the $\mathrm{Fe}-\mathrm{O}$ and $\mathrm{O}-\mathrm{O}$ bonds caused by the reduction and subsequent protonation. Our results show that the $\mathrm{v}(\mathrm{O}-\mathrm{O})$ mode decreases from a superoxo-like frequency near $\sim 1130 \mathrm{~cm}^{-1}$ to $792 \mathrm{~cm}^{-1}$ upon reduction. The latter frequency, as well as its lack of sensitivity to H/D exchange, is consistent with heme-bound peroxide formulation. This species also exhibits a $\mathrm{v}(\mathrm{Fe}-\mathrm{O})$ mode, the $553 \mathrm{~cm}^{-1}$ frequency of which is higher than that observed for the nonreduced oxy P450 precursor $\left(537 \mathrm{~cm}^{-1}\right)$, implying a strengthened $\mathrm{Fe}-\mathrm{O}$ linkage upon reduction. Upon subsequent protonation, the resulting $\mathrm{Fe}-\mathrm{O}-\mathrm{OH}$ fragment exhibits a lowered $\mathrm{v}(\mathrm{O}-\mathrm{O})$ mode at $774 \mathrm{~cm}^{-1}$, whereas the $\mathrm{v}(\mathrm{Fe}-\mathrm{O})$ increases to $564 \mathrm{~cm}^{-1}$. Both modes exhibit a downshift upon H/D exchange, as expected for a hydroperoxo-ferric formulation. These experimental RR data are compared with those previously acquired for the wild-type protein, and the shifts observed upon reduction and subsequent protonation are discussed with reference to theoretical predictions.
\end{abstract}

\title{
Introduction
}

Activation of molecular oxygen by the heme enzymes such as the cytochromes P450, nitric oxide synthase, and heme oxygenase represents a sequence of coordinated events which involve two electron transfers interspersed by the binding of a dioxygen molecule to the heme iron $\underline{1-3}$ (species [2]-[5], Scheme 1 ). As a result, the transient peroxo-ferric complex [5a] is formed, which is readily protonated to form a hydroperoxo-ferric intermediate [5b], often termed Compound 0 . The evaluation of electronic structure of these iron-oxygen intermediates and of the pathways for proton delivery is at the heart of understanding how Nature can utilize atmospheric dioxygen for controlled biological oxidations. 


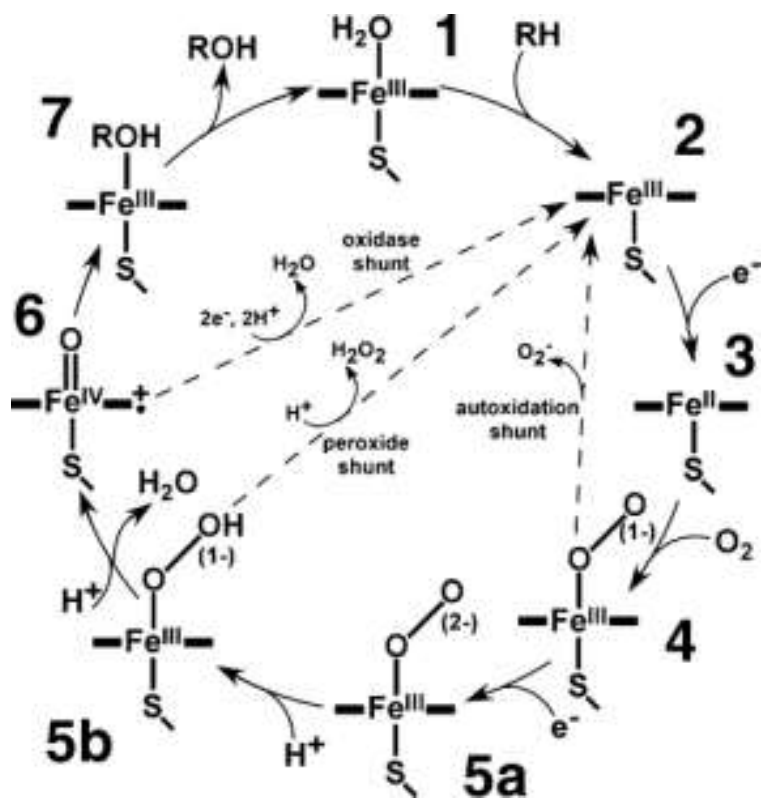

\section{Scheme 1}

The properties of (hydro)peroxo-ferric intermediates on the path of oxygen activation in heme and nonheme systems are the subject of continuing interest in inorganic chemistry and biochemistry. $\frac{4-9}{}$ By using $X$-ray crystallography and multiple spectroscopic methods, a great amount of information has been obtained on the series of mononuclear nonheme iron complexes where a (hydro)peroxide is coordinated in an end-on $\left(\eta^{1}\right)$ or side-on $\left(\eta^{2}\right)$ fashion. In particular, the results of resonance Raman (RR) spectroscopic studies revealed the essential role played by the spin state of $\mathrm{Fe}^{3+}$ in the strength of $\mathrm{Fe}-\mathrm{O}$ and $\mathrm{O}-\mathrm{O}$ bond strengths in the peroxo/hydroperoxo-ferric complexes. ${ }^{4,10-15}$ Recently, considerable progress has been achieved in characterization of similar intermediates in heme proteins obtained by using radiolytic reduction of the oxy-ferrous precursor frozen at cryogenic temperatures. Application of EPR, ENDOR, and Mössbauer spectroscopy provided detailed information on the structure and stability of these complexes in $\mathrm{Hb}, \mathrm{Mb}, \mathrm{P} 450$, and $\mathrm{HO}$ and on the variety of protonation pathways and reactivity of these intermediates. $\frac{16-24}{}$ Several high-resolution X-ray structures of peroxo and hydroperoxo intermediates were also recently obtained by using cryogenic radiolysis, highlighting the importance of active-site details (including solvent) in the transformation of these intermediates. ${ }^{25-28}$ Detailed understanding of the mechanism of formation of [5a] and [5b] and their role in heme enzyme catalysis is also supported by 
many advanced theoretical studies, $\underline{29-34}$ which provide a consistent framework for the general picture of oxygen activation in heme enzymes.

Although a great deal of information is available on the role of iron and porphyrin in the stepwise reduction of dioxygen and on the specific role of sequential protonation steps of the distal oxygen atom of coordinated dioxygen, there is still a considerable lack of information in heme enzymes on the properties of the reduced dioxygen moiety itself, [5a] and [5b], Scheme $\underline{1}$. Theoretical calculations predict a significant lengthening of the $\mathrm{O}-\mathrm{O}$ bond in [5a] as compared to the oxy-ferrous complex [4] and a further increase in O-O distance in [5b]. $\frac{29-34}{}$ These predictions were supported qualitatively by the recent structures of [5a] in $\mathrm{Mb}^{27,28}$ and [5b] in CPO. .26 Note that the resolution of these $X$-ray structures was not high enough to distinguish between [5a] and [5b], and the assignment of protonation state of peroxo/hydroperoxo moiety in these works was based on additional quantum chemical modeling. However, these structures cannot be directly compared because they are obtained in different proteins with different axial ligands trans to the coordinated peroxide, His in $\mathrm{Mb}$ and $\mathrm{Cys}$ in $\mathrm{CPO}$.

The use of an active-site mutant of cytochrome P450 CYP101, in which proton delivery is hampered, provides a unique opportunity to isolate the unprotonated peroxo-ferric intermediate. As a result, a definitive comparison of $\mathrm{Fe}-\mathrm{O}-\mathrm{O}^{-}$and $\mathrm{Fe}-\mathrm{O}-\mathrm{OH}$ fragments is made possible in the present work, wherein we report the first RR study of a cryoreduced oxyferrous complex prepared in the D251N mutant of CYP101. Because the first proton delivery in this mutant is perturbed, $\underline{17,35-39}$ the unprotonated peroxo-ferric intermediate [5a] is observed as the primary species after radiolytic reduction of the oxycomplex in the presence of the substrate camphor at $77 \mathrm{~K} . \underline{17}$ Because camphor hydroxylation in this mutant is fully coupled, although much slower, $\underline{35,36}$ and the hydroperoxo-ferric complex [5b] was identified by EPR and ENDOR after annealing of [5a] at $180 \mathrm{~K}, \underline{17}$ this system represents an ideal opportunity to monitor directly the changes in $\mathrm{Fe}-\mathrm{O}$ and $\mathrm{O}-\mathrm{O}$ bonds caused by the first protonation event and to study both peroxo-ferric [5a] and hydroperoxo-ferric [5b] intermediates by using cryogenic RR spectroscopy. 
NOT THE PUBLISHED VERSION; this is the author's final, peer-reviewed manuscript. The published version may be accessed by following the link in the citation at the bottom of the page.

\section{Methods}

Mutation of CYP101, expression of the mutant D251N CYP101 in $E$. coli, and purification were performed as described. $\underline{40}$ Mutagenesis of the CYP101 gene (pCamT7) was performed by using the Stratagene Quikchange kit following the manufacturer's recommendations. Mutations were confirmed through sequencing of the entire CYP101 gene (ACGT, Wheeling, IL). In order to construct the CYP101 gene with the N-terminal hexahistidine tag (pT7-P450 His), the ends of the gene were modified by using PCR to introduce new restriction cites (Nde 1 and Hind III), and the resulting gene was cloned into pET28(a) vector (Novagen, Madison, WI). Protein was expressed in BL21 (DE3) cells (Stratagene, La Jolla, CA) grown overnight in the presence of 0.5 $\mathrm{mM} \delta$-aminolevulinic acid. After cell sonication, resuspension in $50 \mathrm{mM}$ $\mathrm{KPi} \mathrm{pH} \mathrm{7.4,} 150 \mathrm{mM} \mathrm{KCl}$ (buffer A), and ultracentrifugation, the protein extract was loaded on a Ni-NTA column (Amersham, Piscataway, NJ), washed with buffer $A$ in the presence of $50 \mathrm{mM}$ imidazole, and eluted with the same buffer supplemented with 20 mM EDTA. The resulting red fractions were dialyzed in $50 \mathrm{mM} \mathrm{KPi}, 400 \mu \mathrm{M}$ d-camphor, $20 \mathrm{mM}$ $\beta$-mercaptoethanol, $\mathrm{pH} 7.4$ (designated as RB buffer) overnight at $4{ }^{\circ} \mathrm{C}$. Solid ammonium sulfate was added to $30 \%$ saturation over 30 min, and the protein was subsequently loaded onto a PhenylSepharose CL6B column equilibrated in the same buffer and eluted in a linear gradient from 30 to $0 \%$ ammonium sulfate. Resulting fractions with an Rz value $\left(A_{391} / A_{280}\right)$ greater than 1.45 were judged as pure and concentrated by using an Amicon cell.

All samples for Raman and UV-vis spectroscopy contained 100 $\mathrm{mM} \mathrm{KPi} \mathrm{pH} \mathrm{7.4,} 100 \mathrm{mM} \mathrm{KCl}$, and $0.6 \mathrm{mM}$ d-camphor. Samples of oxyferrous CYP101 for the RR spectroscopy were prepared as described previously $\frac{41,42}{}$ with the minor modifications listed below. Concentrated solutions of ferric CYP101 were deaerated under a stream of Ar gas, mixed with the degassed 9:1 v/v mixture of glycerol and $1 \mathrm{M}$ phosphate buffer in an anaerobic chamber (Coy Laboratory Products, Grass Lake, MI) to the final glycerol/buffer ratio $3: 7 \mathrm{v} / \mathrm{v}$, and placed into the $5 \mathrm{~mm}$ NMR glass tubes (Wilmad LabGlass, Buena, NJ). CYP101 was reduced by anaerobic addition of a small molar excess of dithionite by using a solution of known concentration, determined spectrophotometrically by using a molar absorption coefficient $\varepsilon_{315}=$ 
$8050 \mathrm{M}^{-1} \mathrm{~cm}^{-1}$. Complete reduction was verified by absorption spectroscopy. Oxygenation of the ferrous CYP101 samples was done directly in NMR tubes connected to the Schlenck line at $4{ }^{\circ} \mathrm{C}$ by sequential application of vacuum, high purity argon, vacuum, and then ${ }^{16} \mathrm{O}_{2}$ or ${ }^{18} \mathrm{O}_{2}$ gas followed by quick vortexing to facilitate oxygenation. Oxygenated samples were immediately frozen in liquid nitrogen to minimize autoxidative decomposition of oxy-ferrous CYP101.

Samples of oxy-ferrous CYP101 for the UV-vis absorption spectroscopy were prepared in UV-enhanced methacrylate semimicro spectroscopic cells (Fisher Scientific, Allentown, PA) as described. 43,44 Different concentrations, from 20 to $80 \mu \mathrm{M}$, and an optical path length of $4.3 \mathrm{~mm}$ were used for accurate determination of absorption spectra in the Soret and Q-band regions and for the optimal background subtraction (see below). To ensure formation of clear transparent glassy solvent matrix, a high glycerol content, $2: 1 \mathrm{v} / \mathrm{v}$, was used as described previously. $\stackrel{43,44}{ }$ Samples for absorption spectroscopy were irradiated together with the RR samples to generate the peroxo-ferric intermediate and illuminated at $77 \mathrm{~K}$ for 8-12 min before measurement in order to bleach the strong absorption from trapped electrons generated during radiolysis. $\frac{44}{}$ Absorption spectra of all samples were measured before and after irradiation at different temperatures in the range $80-200 \mathrm{~K}$ by using the homemade cryostat

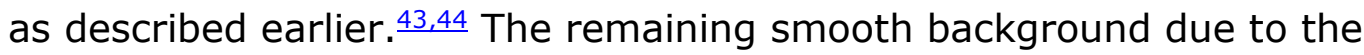
radicals generated by radiolysis in the aqueous glycerol solvent matrix was the same in all samples with different CYP101 concentrations and could be eliminated by subtraction of the spectrum of the sample with the lowest concentration of CYP101 from all other spectra taken at the same temperatures.

Frozen samples of oxy-ferrous CYP101 were irradiated with 4 Mrad of $\underline{60}$ Co $Y$ rays at $77 \mathrm{~K}$ and a dose rate $0.95 \mathrm{Mrad} /$ hour. X-Band EPR experiments were performed at the University of Illinois EPR Resource Center on a Varian E-122 X-Band (9.03 GHz) spectrometer, by using microwave power of $0.5 \mathrm{~mW}$ and modulation amplitude of 5 Gauss at $100 \mathrm{kHz}$. An Air Products (Allentown, PA) liquid helium flow system was used for measurements at $15 \mathrm{~K}$. 
The RR spectra were acquired by using a Spex 1269 spectrometer equipped with a Newton EMCCD detector (Model DU971, Andor Technologies). The $413.1 \mathrm{~nm}$ line from a $\mathrm{Kr}^{+}$laser (Coherent Innova Model 100-K3) was used to measure spectra of oxygenated samples before irradiation, whereas the $441.6 \mathrm{~nm}$ line provided by a $\mathrm{He}-\mathrm{Cd}$ laser (Liconix Model 4240) was used for probing the irradiated and annealed samples. The RR spectra were collected by using a back scattering $\left(180^{\circ}\right)$ geometry with the laser beam (power of $1.0 \mathrm{~mW}$ or less) being focused by a cylindrical lens to form a line image on the sample. All measurements were taken at $77 \mathrm{~K}$. The frozen samples were contained in $5 \mathrm{~mm}$ o.d. NMR tubes (WG-5 ECONOMY, Wilmad). The NMR tubes were positioned into a double-walled quartz lowtemperature cell of in-house design filled with liquid nitrogen. The sample tubes were spun to avoid local heating by the laser beam. Spectra were calibrated with fenchone and processed with Grams/32 AI software (ThermoGalactic, Salem, NH).

\section{Results}

In order to document the changes of the $\mathrm{Fe}-\mathrm{O}-\mathrm{O}$ moiety in the key iron-oxygen intermediates of P450 catalysis, we have prepared intermediates [4], [5a], and [5b] in the D251N mutant of CYP101 and studied these complexes by using RR spectroscopy. As described earlier, $\underline{17,18}$ the cryogenic radiolytic reduction of oxy-ferrous complex [4] in this mutant CYP101 results in the formation of the unprotonated state [5a], which is stable at $77 \mathrm{~K}$ and undergoes protonation to afford [5b] after brief annealing above $180 \mathrm{~K}$. By using cryogenic Raman spectroscopy, we have measured the RR spectra of these intermediates before and after protonation and assigned the positions of $\mathrm{v}(\mathrm{O}-\mathrm{O})$ and $\mathrm{v}(\mathrm{Fe}-\mathrm{O})$ modes. The protonation state of both intermediates [5a] and [5b] was confirmed by the EPR spectroscopic signatures of these states before and after annealing at $185 \mathrm{~K}$, respectively. Both EPR and Raman data sets were obtained by using the same samples, to ensure the proper assignment of the spectroscopic results. In addition, the UV-vis absorption spectra of complexes [4], [5a], and [5b] are also reported herein. 


\section{A Electronic and EPR Spectroscopy}

We measured EPR spectra on the same samples used in the Raman experiments, both before and after Raman measurements, to confirm formation of the peroxo-ferric complex [5a] in CYP101 immediately after irradiation at $77 \mathrm{~K}$ and to monitor protonation of this intermediate and formation of the hydroperoxo-ferric complex [5b] after annealing at $185 \mathrm{~K}$. As shown in Figure $1 \mathrm{~A}, \mathrm{X}$-band EPR spectra of the cryoreduced oxy-ferrous D251N mutant of CYP101 measured after irradiation displayed a low-spin rhombic species with $g$-values $[2.245,2.16,1.95]$ diagnostic of an unprotonated ferric-peroxo moiety with end-on ( $\eta 1$ ) geometry, in agreement with the earlier Q-band EPR studies of the same mutant in CYP101.17 After annealing to $185 \mathrm{~K}$, an almost complete conversion to the protonated ferric peroxo species with $g$-values $[2.29,2.17,1.95]$ is observed (Figure $1 \mathrm{~A})$, again confirming earlier results. $\frac{17}{}$
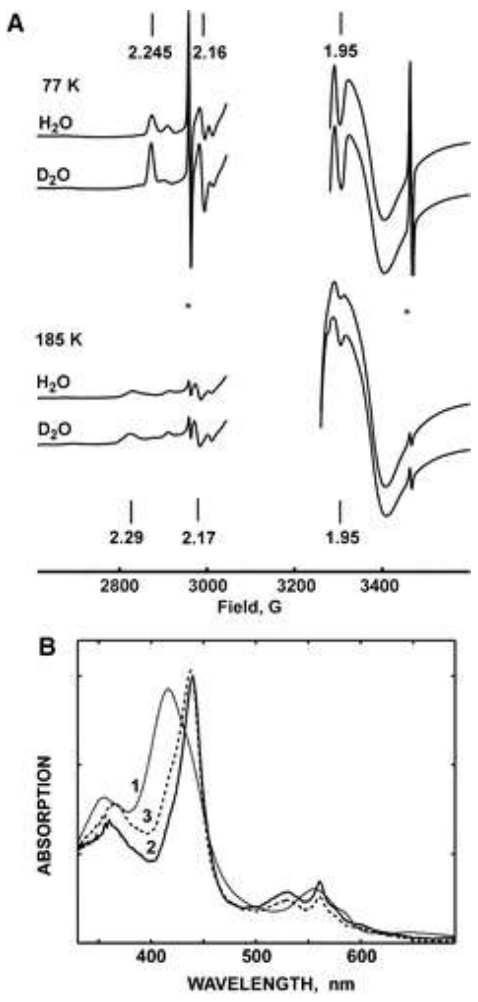

Figure 1. (A) EPR spectra of the reduced oxy-ferrous complex of D251N CYP101. Data measured after irradiation at $77 \mathrm{~K}$ and after all RR experiments and annealing at 185 $\mathrm{K}$. The hydrogen atom doublet is marked by the star sign. Vertical bars indicate the features of peroxo-ferric (upper line) and hydroperoxo-ferric (bottom line) complexes 
with the corresponding $g$-values. Frozen samples are in $100 \mathrm{mM}$ phosphate $\left(\mathrm{H}_{2} \mathrm{O}\right.$ or $\mathrm{D}_{2} \mathrm{O}$, as indicated), $100 \mathrm{mM} \mathrm{KCl}, 30 \%$ glycerol $\mathrm{v} / \mathrm{v}, T=15 \mathrm{~K}$. Other details of EPR spectroscopy are described in Methods. (B) Absorption spectra of D251N CYP101: (1) Oxy-ferrous complex, $T=85 \mathrm{~K}$, before irradiation; (2) peroxo-ferric complex, $90 \mathrm{~K}$, after irradiation at $77 \mathrm{~K}$; and (3) hydroperoxo-ferric complex, $180 \mathrm{~K}$, after irradiation at $77 \mathrm{~K}$ and annealing at $185 \mathrm{~K}$. Frozen samples are in $100 \mathrm{mM}$ phosphate $\left(\mathrm{H}_{2} \mathrm{O}\right), 100$ $\mathrm{mM} \mathrm{KCl}, \mathrm{pH} 7.4,65 \%$ glycerol.

The transitions in protonation state of the cryoreduced oxy P450 mutant are similarly reflected in low-temperature optical spectroscopy experiments (Figure $1 \mathrm{~B}$ ), with the spectrum of the parent, nonreduced, dioxygen adduct being shown for reference. The features of the absorption spectrum of the reduced oxy-ferrous complex of the mutant protein at $90-120 \mathrm{~K}$ in both the split Soret band (main maximum at $439 \mathrm{~nm}$ with the second one at $361 \mathrm{~nm}$ ) and Q-band ( $\mathrm{a}$ and $\beta$ bands at 561 and $530 \mathrm{~nm}$, respectively) are similar to those obtained in analogous experiments with the CYP101 reported earlier. $\frac{43,44}{4}$ Upon annealing from 90 to $180 \mathrm{~K}$, the Soret band shifts to $437 \mathrm{~nm}$, and the second band shifts to $365 \mathrm{~nm}$, indicating the decreased splitting in [5b] as compared to [5a] with only minor changes observable in intensities of the $Q$ bands. These small changes are consistent with the protonation of [5a] and formation of the hydroperoxo-ferric intermediate $[\mathbf{5 b}] .17$

\section{B RR Spectroscopy}

RR spectroscopy is the most powerful method for providing direct information about $\mathrm{Fe}-\mathrm{X}-\mathrm{Y}$ bond strengths and, through the observation of hydrogen-deuterium isotope shifts of corresponding vibrational modes, reveals important details concerning the protonation state of $\mathrm{H} / \mathrm{D}$-exchangeable groups, such as the peroxoferric fragments of interest here. In this work, we present the RR characterization of the precursor dioxygen adduct [4] and each of the cryoreduced forms $[\mathbf{5 a}]$ and $[\mathbf{5 b}]$.

\section{Dioxygen Adduct(s) of D251N}

Two series of isotopically $\left({ }^{16} \mathrm{O}_{2}\right.$ and $\left.{ }^{18} \mathrm{O}_{2}\right)$ labeled samples of D251N were prepared in $\mathrm{H}_{2} \mathrm{O}$ and $\mathrm{D}_{2} \mathrm{O}$ buffers, and their RR spectra were collected before irradiation in order to establish the vibrational signature of this oxygenated precursor and to document successful 
isotopic labeling. The high frequency RR spectrum of oxygenated D251N is shown in trace A of Figure $\underline{2}$. This spectrum resembles that already published earlier by Sjodin et al., $\frac{45}{}$ with a strong, slightly broadened, band centered near $1134 \mathrm{~cm}^{-1}$ that is attributable to bands associated with the $\mathrm{v}\left({ }^{16} \mathrm{O}-{ }^{16} \mathrm{O}\right)$ stretching mode. As was pointed out in earlier work, $\underline{45}$ this broadened band is most reasonably interpreted to reflect the existence of two or three structural conformers of the $\mathrm{Fe}-\mathrm{O}-\mathrm{O}$ fragment. It was concluded 45 that for both the wild-type (WT) and $\mathrm{D} 251 \mathrm{~N}$ oxygenated proteins, there is one major conformer exhibiting its $\left.\mathrm{v}^{16} \mathrm{O}-{ }^{16} \mathrm{O}\right)$ at 1138 or $1136 \mathrm{~cm}^{-1}$, respectively, with both proteins having two minor conformers detected at 1146 and near 1130 $\mathrm{cm}^{-1}$. Interestingly, it was also shown that upon binding of its reduced electron transfer partner putidaredoxin (Pd) to the D251N mutant, the $1129 \mathrm{~cm}^{-1}$ component was populated to an extent nearly comparable to the $1137 \mathrm{~cm}^{-1}$ species; that is, two nearly equally intense bands were observed. $\underline{45}$

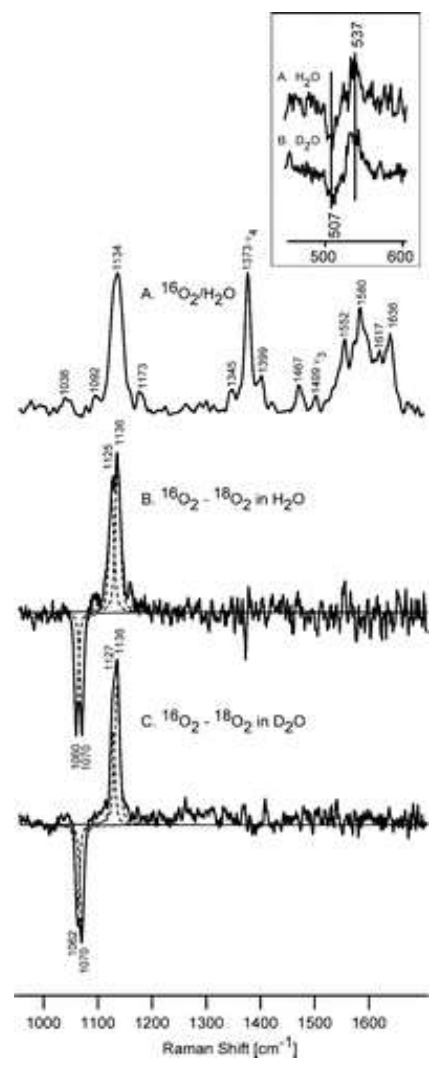

Figure 2. High-frequency RR spectra of oxy D251N CYP101 measured at $77 \mathrm{~K}$ and difference spectra before irradiation (excitation at $413 \mathrm{~nm}$ ). Inset shows low-frequency difference spectra of ${ }^{16} \mathrm{O}_{2}-{ }^{18} \mathrm{O}_{2}$ in $\mathrm{H}_{2} \mathrm{O}(A)$ and in $\mathrm{D}_{2} \mathrm{O}$ (B) buffer.

Journal of Physical Chemistry A, Vol 112, No. 50 (December 18, 2008): pg. 13172-13179. DOI. This article is @ American Chemical Society and permission has been granted for this version to appear in e-Publications@Marquette. American Chemical Society does not grant permission for this article to be further copied/distributed or hosted elsewhere without the express permission from American Chemical Society. 
As will be discussed, our new data acquired at $77 \mathrm{~K}$ not only support this previous suggestion of multiple conformers but reveal the fact that the difference in the two major conformers appearing at 1136 and $1125 \mathrm{~cm}^{-1}$ at $77 \mathrm{~K}$ is associated with changes in $\mathrm{H}$-bonding. Thus, careful inspection of the spectra (traces $B$ and $C$ of Figure $\underline{2}$ ) reveals the existence of two isotope-sensitive modes, the vibrational parameters of which can be extracted by fitting the difference traces with 50/50 Gaussian/Lorentzian profiles. It was found that the broad positive feature centered at around $1134 \mathrm{~cm}^{-1}$, as well as the negative one centered at around $1065 \mathrm{~cm}^{-1}$ in trace $\mathrm{B}$, had apparent bandwidths of $22-23 \mathrm{~cm}^{-1}$, whereas the relatively isolated heme mode, $v_{4}$, appearing at $1373 \mathrm{~cm}^{-1}$, had a bandwidth of $12 \mathrm{~cm}^{-1}$. Not surprisingly, the best fit of those isotope-sensitive features is achieved by using two functions that had $11-12 \mathrm{~cm}^{-1}$ bandwidth, yielding two modes at 1136 and $1125 \mathrm{~cm}^{-1}$ exhibiting 66 and $65 \mathrm{~cm}^{-1}$ shifts upon ${ }^{18} \mathrm{O}_{2}$ substitution, respectively, in agreement with that predicted by Hooke's law. Moreover, the results obtained with the samples prepared in deuterated solvent show that the lower frequency $\mathrm{v}(\mathrm{O}-\mathrm{O})$ stretch exhibits a clear $2 \mathrm{~cm}^{-1}$ upshift upon $\mathrm{D}_{2} \mathrm{O}$ exchange, which suggests that the lower frequency conformer is in fact participating in a hydrogen bonding interaction with a distal side residue apparently different than that corresponding to the higher-frequency conformer. It is important to emphasize that in the spectra of oxygenated WT CYP101 at $77 \mathrm{~K}$, only one strong $\mathrm{v}(\mathrm{O}-\mathrm{O})$ stretch was detected at 1139 $\mathrm{cm}^{-1}$, which also failed to exhibit an H/D shift. $\underline{42}$ Thus, the present work shows that the population of this type of second conformer actually occurs merely by lowering the temperature of the oxygenated $\mathrm{D} 251 \mathrm{~N}$ mutant to $77 \mathrm{~K}$ and does not require binding of $\mathrm{Pd} . \underline{45}$

The lower frequency of the proposed $\mathrm{H}$-bonded form is consistent with early work with model compounds where, by comparing $\mathrm{v}(\mathrm{O}-\mathrm{O})$ stretching frequencies of dioxygen adducts of pyridine ligated CoTPP with those of corresponding picket-fence derivatives, it was demonstrated that the picket-fence adducts exhibited significantly (up to $5 \mathrm{~cm}^{-1}$ ) lower frequencies, a shift that was reasonably attributed to $\mathrm{H}$-bonding interactions with the amide linkages of the picketfence fragments. $\frac{46}{}$ Furthermore, in recent RR studies of dioxygen ligated NOS isoforms, shifts of precisely this magnitude have been attributed to $\mathrm{H}$-bonding differences; that is, the

Journal of Physical Chemistry A, Vol 112, No. 50 (December 18, 2008): pg. 13172-13179. DOI. This article is @ American Chemical Society and permission has been granted for this version to appear in e-Publications@Marquette. American Chemical Society does not grant permission for this article to be further copied/distributed or hosted elsewhere without the express permission from American Chemical Society. 
substrate-free dioxygen adduct exhibited a $\mathrm{v}(\mathrm{O}-\mathrm{O})$ at $1133 \mathrm{~cm}^{-1}$, whereas that of the arginine-bound form was observed at $1126 \mathrm{~cm}^{-1}$. 47

By referring to the sensitivity to deuterium substitution, although $\mathrm{H} / \mathrm{D}$ induced $2-5 \mathrm{~cm}^{-1}$ shifts to higher frequency of the $\mathrm{v}(\mathrm{O}-\mathrm{O})$ modes of dioxygen adducts of cobalt-substituted globins have been plausibly attributed to $\mathrm{D}$ - versus $\mathrm{H}$-bonding interactions, $\underline{48}$ it has been demonstrated that such interpretations are potentially compromised by complications arising from unusually strong vibrational coupling interactions between the $\mathrm{v}(\mathrm{O}-\mathrm{O})$ mode and internal modes of the trans-axial histidyl imidazole, the coupling patterns changing as the latter modes shift in response to $H / D$ exchange at the imidazole $\mathrm{H}-\mathrm{N}$ fragment. $\frac{49-51}{1 n}$ the present case, however, the absence of the trans-axial imidazole obviates consideration of such complications, and the $2 \mathrm{~cm}^{-1}$ upshift can reasonably be attributed to $\mathrm{H}$-bonding; in fact, a recent $\mathrm{RR}$ study of dioxygen adducts of cytochrome P450 model compounds, in which hydroxyl groups were incorporated into the distal pocket to serve as $\mathrm{H}$-bond donors to the bound dioxygen, the $\mathrm{v}(\mathrm{O}-\mathrm{O})$ band indeed displayed an identical $2 \mathrm{~cm}^{-1}$ shift to higher frequency upon $H / D$ exchange of the distal pocket hydroxyl groups. $\underline{52}$

The low frequency spectra of oxygenated D251N samples (Figure 2 , inset) exhibit a feature in the $\mathrm{v}\left(\mathrm{Fe}-\mathrm{O}_{2}\right)$ stretching region at $537 \mathrm{~cm}^{-1}$ that shifts down by $30 \mathrm{~cm}^{-1}$ upon ${ }^{18} \mathrm{O}_{2}$ substitution. On the basis of the observation of two $\mathrm{v}(\mathrm{O}-\mathrm{O})$ modes in the high-frequency region, it might have been expected that two $v(\mathrm{Fe}-\mathrm{O})$ modes would be observed in the low-frequency region. Owing to the relatively low S/N ratio seen here, however, no significant broadening is discernible, and no clear H/D shift is detected (Table 1 ). Such H/D shifts, if present, are indeed expected to be quite small and are not normally observed for these low-frequency $\mathrm{v}\left(\mathrm{M}-\mathrm{O}_{2}\right)$ modes. $\frac{45,53-56}{}$ Although we have obtained no clear evidence for separation of the $\mathrm{v}(\mathrm{Fe}-\mathrm{O})$ region into two distinct features, similarly to earlier results,,$\underline{45}$ we note the presence of the positive correlation between the $\mathrm{v}(\mathrm{Fe}-\mathrm{O})$ and $\mathrm{v}(\mathrm{O}-\mathrm{O})$ modes. The presence of a lower-frequency $\mathrm{v}(\mathrm{O}-\mathrm{O})$ mode at $1125 \mathrm{~cm}^{-1}$ is correlated with an apparent shift to lower frequency for the observed $\mathrm{v}(\mathrm{Fe}-\mathrm{O})$ mode(s) from 546 to $537 \mathrm{~cm}^{-1}$.

Table 1. Frequencies of Isotopically Sensitive Modes of WT and D251N Mutant of CYP101 and their Isotopic Shifts (Spectra Measured at $77 \mathrm{~K}$ ) 
NOT THE PUBLISHED VERSION; this is the author's final, peer-reviewed manuscript. The published version may be accessed by following the link in the citation at the bottom of the page.

frequency and isotopic shift $\left[\mathrm{cm}^{-1}\right]$

$$
\mathrm{v}(\mathrm{Fe}-\mathrm{O}) \Delta\left[{ }^{16} \mathrm{O}_{2} /{ }^{18} \mathrm{O}_{2} ; \mathrm{H}_{2} \mathrm{O} / \mathrm{D}_{2} \mathrm{O}\right] \quad \mathrm{v}(\mathrm{O}-\mathrm{O}) \Delta\left[{ }^{16} \mathrm{O}_{2} /{ }^{18} \mathrm{O}_{2} ; \mathrm{H}_{2} \mathrm{O} / \mathrm{D}_{2} \mathrm{O}\right]
$$

WTa

$$
\begin{aligned}
& \mathrm{Fe}(\mathrm{II})-\mathrm{O}_{2}[4] \quad 546[31 ; 0] \quad 1139[66 ; 0] \\
& \mathrm{Fe}(\mathrm{III})-\mathrm{O}_{2}{ }^{2-}[\mathbf{5 a}] \\
& \mathrm{Fe}(\mathrm{III})-\mathrm{O}_{2} \mathrm{H}^{-} \text {[5b] } 559[27 ; 3] \\
& 799[40 ; 3] \\
& \text { D251N } \\
& \mathrm{Fe}(\mathrm{II})-\mathrm{O}_{2}[4] \quad 537[30 ; 0] \\
& \mathrm{Fe}(\mathrm{III})-\mathrm{O}_{2}{ }^{2-}[\mathbf{5 a}] \quad 553[27 ; 0] \\
& 1136[66 ; 0] 1125[65 ;+2]^{\underline{b}} \\
& \mathrm{Fe}(\mathrm{III})-\mathrm{O}_{2} \mathrm{H}^{-} \text {[5b] } 564[28 ; 2] \\
& 792[38 ; 0] \\
& 774[37 ; 4]
\end{aligned}
$$

a Data from ref $\underline{42}$.

b Plus sign indicates shift to higher frequency, opposite to the normally observed direction.

\section{Irradiated and Annealed Samples of OxyD251N}

The RR spectra of irradiated oxyD251N samples show two isotopically sensitive species (Figure $\underline{3}$ ). The mode observed in the spectra of ${ }^{16} \mathrm{O}_{2}$ in $\mathrm{H}_{2} \mathrm{O}$ at $553 \mathrm{~cm}^{-1}$ shows a $27 \mathrm{~cm}^{-1}$ down shift upon ${ }^{18} \mathrm{O}_{2}$ substitution. The other isotopically sensitive mode at $792 \mathrm{~cm}^{-1}$ exhibits the expected $38 \mathrm{~cm}^{-1}$ down shift upon ${ }^{16} \mathrm{O}_{2} /{ }^{18} \mathrm{O}_{2}$ exchange (Table 1). Most importantly, neither of these modes exhibit $\mathrm{H}_{2} \mathrm{O} / \mathrm{D}_{2} \mathrm{O}$ sensitivity, an observation most consistent with the assignment of these features to the $\mathrm{v}\left(\mathrm{Fe}-\mathrm{O}\right.$ ) (at $553 \mathrm{~cm}^{-1}$ ) and $\mathrm{v}(\mathrm{O}-\mathrm{O}$ ) (at 792 $\mathrm{cm}^{-1}$ ) modes of a peroxo species. Note that distinct H/D shifts have been documented for these modes for the hydroperoxo intermediate of the WT protein. .22 This is the first direct observation of the vibrational frequencies of the nonprotonated peroxo intermediate [5a] of a member of the cytochrome P450 protein family, and its assignment is consistent with earlier EPR and absorption spectroscopic studies. ${ }^{17,18}$ 


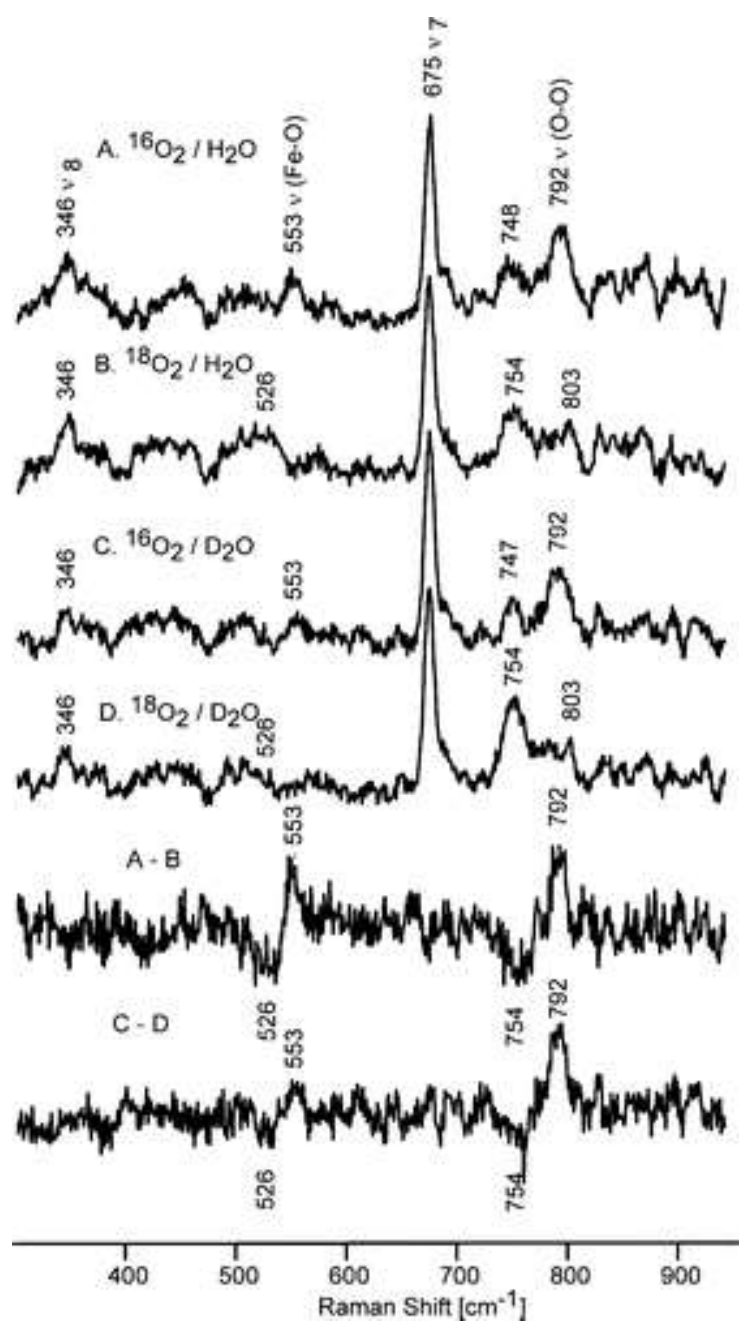

Figure 3. RR spectra of irradiated $\mathrm{P} 450 \mathrm{D} 251 \mathrm{~N}$ samples in $\mathrm{H}_{2} \mathrm{O}$ buffer, spectra $A$ $\left({ }^{16} \mathrm{O}_{2}\right)$ and $\mathrm{B}\left({ }^{18} \mathrm{O}_{2}\right)$, and in the $\mathrm{D}_{2} \mathrm{O}$ buffer, spectra $\mathrm{C}\left({ }^{16} \mathrm{O}_{2}\right)$ and $\mathrm{D}\left((18) \mathrm{O}_{2}\right)$. The two bottom traces shows the difference spectra of ${ }^{16} \mathrm{O}_{2}-{ }^{18} \mathrm{O}_{2}$ in $\mathrm{H}_{2} \mathrm{O}$ and ${ }^{16} \mathrm{O}_{2}-{ }^{18} \mathrm{O}_{2}$ in $\mathrm{D}_{2} \mathrm{O}$ buffer (excitation line $442 \mathrm{~nm}$, temperature $77 \mathrm{~K}$ ).

Earlier, it was shown that annealing of such irradiated samples to higher temperatures (above $170 \mathrm{~K}$ ) allows protonation of this peroxo species to yield the hydroperoxo form. $\frac{17,18}{18}$ Consistent with this picture, the spectra of our samples annealed to $185 \mathrm{~K}$ and then cooled to $77 \mathrm{~K}$ for RR measurements are presented in Figure $\underline{4}$ and document a difference pattern of isotopically sensitive modes that is similar to that observed before annealing but which reveals distinctly different component frequencies. The mode appearing at $564 \mathrm{~cm}^{-1}$, seen in the trace A of Figure $\underline{4}$, exhibits a $28 \mathrm{~cm}^{-1}$ downshift upon ${ }^{18} \mathrm{O}_{2}$ substitution as well as a $2 \mathrm{~cm}^{-1}$ downshift in $\mathrm{D}_{2} \mathrm{O}$ buffer. Moreover, the higher- 
frequency mode at $774 \mathrm{~cm}^{-1}$ shifts down by 37 and $4 \mathrm{~cm}^{-1}$ upon ${ }^{18} \mathrm{O}_{2}$ and $H / D$ exchange, respectively (Table $\underline{1}$ ). Those H/D shifts are in a good agreement with previously published RR data for known metallohydroperoxo species $4,41,42,57$ and are consistent with the hydroperoxo formulation derived from EPR and UV-vis data for annealed samples of irradiated D251N. 17 Clearly, the modes at 564 and $774 \mathrm{~cm}^{-1}$ are most reasonably assigned as the $\mathrm{v}(\mathrm{Fe}-\mathrm{O})$ and $\mathrm{v}(\mathrm{O}-\mathrm{O})$ modes of the hydroperoxo-ferric species [5b], respectively.

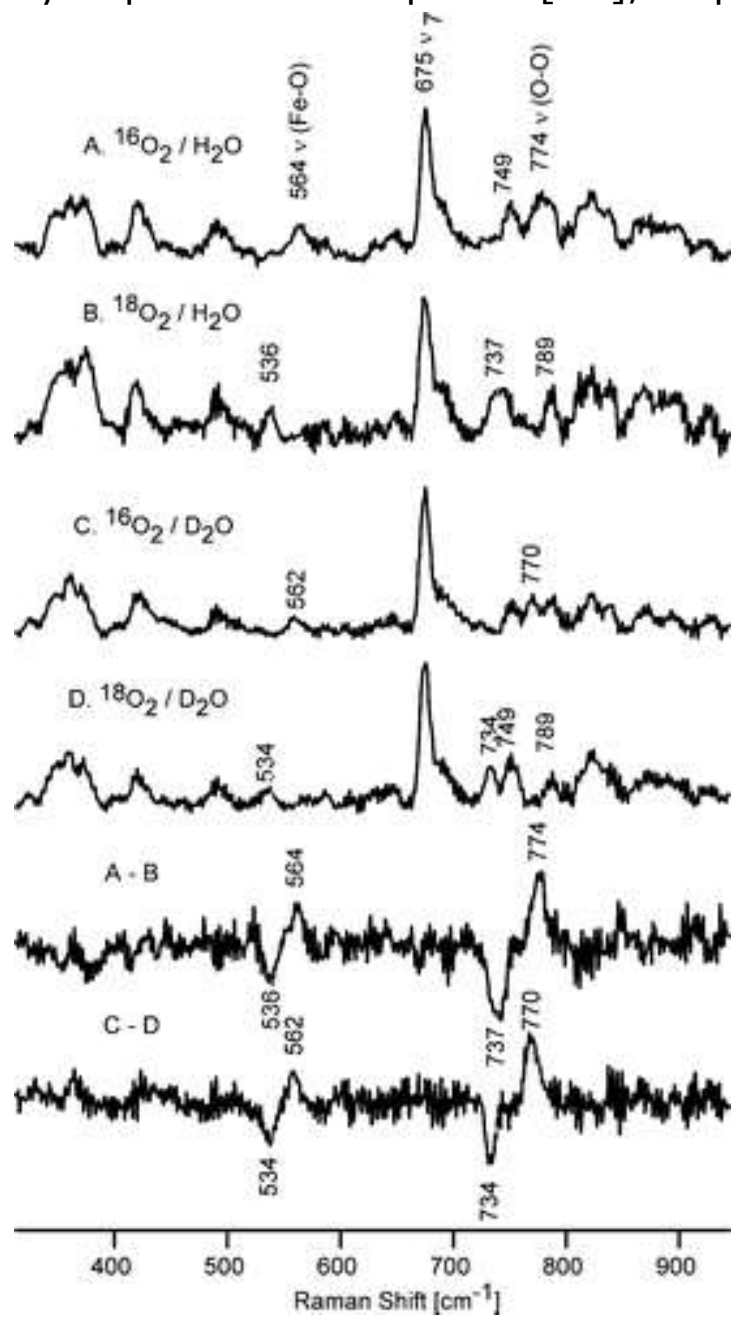

Figure 4. $\mathrm{RR}$ spectra of irradiated and annealed at $185 \mathrm{~K}$ samples of $\mathrm{P} 450 \mathrm{D} 251 \mathrm{~N}$ in $\mathrm{H}_{2} \mathrm{O}$ buffer, spectra $A\left({ }^{16} \mathrm{O}_{2}\right)$ and $\mathrm{B}\left({ }^{18} \mathrm{O}_{2}\right)$, and in the $\mathrm{D}_{2} \mathrm{O}$ buffer, spectra $\mathrm{C}\left({ }^{16} \mathrm{O}_{2}\right)$ and $D\left({ }^{18} \mathrm{O}_{2}\right)$. The two bottom traces shows the difference spectra of ${ }^{16} \mathrm{O}_{2}-{ }^{18} \mathrm{O}_{2}$ in $\mathrm{H}_{2} \mathrm{O}$ and ${ }^{16} \mathrm{O}_{2}-{ }^{18} \mathrm{O}_{2}$ in $\mathrm{D}_{2} \mathrm{O}$ buffer (excitation at $442 \mathrm{~nm}$, temperature $77 \mathrm{~K}$ ).

Further annealing to higher temperatures (195 and $205 \mathrm{~K}$ ) did not lead to the observation of any new isotopically sensitive modes, at

Journal of Physical Chemistry A, Vol 112, No. 50 (December 18, 2008): pg. 13172-13179. DOI. This article is @ American Chemical Society and permission has been granted for this version to appear in e-Publications@Marquette. American Chemical Society does not grant permission for this article to be further copied/distributed or hosted elsewhere without the express permission from American Chemical Society. 
least when employing the $442 \mathrm{~nm}$ excitation line used here for the peroxo/hydroperoxo forms (Figure S1, Supporting Information). Future work, employing higher concentrations, different excitation lines, and other solution conditions, including the use of different substrates, will be conducted in order to search for these later, highly reactive intermediates.

\section{Discussion}

In this study, we document the changes in the Fe-O-O moiety monitored by RR spectroscopy in the key intermediates of dioxygen activation in the cytochromes P450. The isolation and separate spectroscopic studies of unprotonated peroxo-ferric and protonated hydroperoxo-ferric complexes [5a] and [5b] have been made possible by using the D251N mutant of CYP101, which yields exclusively [5a] as a results of cryogenic radiolytic reduction of [4]. $\frac{17,18}{12}$ The protonation states of [5a] as prepared at $77 \mathrm{~K}$ and of [5b] after annealing at $185 \mathrm{~K}$ have been assigned by using characteristic EPR signature spectra, measured on the same samples used for the Raman spectroscopy. As a result, we can compare for the first time the vibrational modes $\mathrm{v}(\mathrm{O}-\mathrm{O})$ and $\mathrm{v}(\mathrm{Fe}-\mathrm{O})$ measured for [4], [5a], and [5b] on the same sample to evaluate the effects of the one-electron reduction and of protonation on the structure and stability of these intermediates of dioxygen activation.

The RR spectra of the dioxygen adduct [4] of the D251N protein show small but distinct differences from the corresponding spectra of the WT protein. $\frac{42}{\text { The }} \mathrm{D} 251 \mathrm{~N}$ adduct exhibits two relatively strong $\mathrm{v}(\mathrm{O}-\mathrm{O})$ stretching modes at 1136 and $1125 \mathrm{~cm}^{-1}$, whereas the WT shows only one intense mode near $1139 \mathrm{~cm}^{-1}$. Neither the 1136 (D251N) nor the $1139 \mathrm{~cm}^{-1}$ (WT) features are sensitive to H/D exchange, but the $1125 \mathrm{~cm}^{-1}$ mode of the mutant exhibits a distinct 2 $\mathrm{cm}^{-1}$ shift to higher frequency in the deuterated solutions (Figure $\underline{2}$ ), implying that one effect of the D251N mutation is to facilitate substantial population of a second conformer, a result in agreement with more recent crystallographic data. $\frac{58}{}$ Although early crystallographic studies of the oxygenated complex of the D251N mutant did not show multiple conformers, $\underline{59}$ more recent work indicates that two conformations of the Asn251-Thr252 region of the 
protein are present in crystals of the dioxygen adduct of D251N CYP101. $\underline{58}$

The frequencies of the $\mathrm{v}(\mathrm{O}-\mathrm{O})$ and $\mathrm{v}(\mathrm{Fe}-\mathrm{O})$ modes for all species detected here and in the previous study of the hydroperoxo form of the WT protein are collected in Table $\underline{1}$. As mentioned, cryoradiolysis of the oxygenated WT protein at $77 \mathrm{~K}$ yields directly the hydroperoxo derivative [5a], the $\mathrm{v}(\mathrm{O}-\mathrm{O})$ and $\mathrm{v}(\mathrm{Fe}-\mathrm{O})$ modes of which appear at 799 and $559 \mathrm{~cm}^{-1}$, respectively, both exhibiting telltale shifts to lower frequency in $\mathrm{D}_{2} \mathrm{O}$ solutions. $\underline{42}$ Given that the most significant effect of the D251N mutation is to restrict proton delivery to the initially formed ferri-peroxo fragment, it is not surprising that, as shown previously, $\underline{17,18}$ this species is trapped at $77 \mathrm{~K}$ and, as shown here, exhibits $\mathrm{v}(\mathrm{O}-\mathrm{O})$ and $\mathrm{v}(\mathrm{Fe}-\mathrm{O})$ modes at 792 and $553 \mathrm{~cm}^{-1}$, neither of which shows any sensitivity to H/D exchange. This strongly suggests that these modes refer to the peroxo-ferric intermediate [5a]. The hydroperoxo derivative of D251N [5b], formed upon annealing to higher temperatures, exhibits a substantially lowerfrequency $\mathrm{v}(\mathrm{O}-\mathrm{O})$ mode at $774 \mathrm{~cm}^{-1}$ and a significantly higherfrequency $\mathrm{v}\left(\mathrm{Fe}-\mathrm{O}\right.$ ) mode (i.e., $564 \mathrm{~cm}^{-1}$ ) compared to its nonprotonated precursor. By assuming that a similar $\left(18 \mathrm{~cm}^{-1}\right)$ shift of $\mathrm{v}(\mathrm{O}-\mathrm{O})$ for transition between [5a] and [5b] occurs for the WT protein, the estimated frequency for the unobservable reactive peroxoferric [5a] derivative of WT CYP101 would be $\sim 817 \mathrm{~cm}^{-1}$, that is, 799 $+18 \mathrm{~cm}^{-1}$. On the basis of this estimated frequency for the [5a] form of the WT protein, the shift in $\mathrm{v}(\mathrm{O}-\mathrm{O})$ upon conversion from peroxo to hydroperoxo forms for both proteins would be $18 \mathrm{~cm}^{-1}$, and the observed shifts in comparing similar forms of both proteins are 25 $\mathrm{cm}^{-1}$. For both the [5a] and [5b] states, $\mathrm{v}(\mathrm{O}-\mathrm{O})$ in the mutant is 25 $\mathrm{cm}^{-1}$ lower than that in the WT protein. Thus, not only does the mutation retard proton delivery to the $\mathrm{Fe}-\mathrm{O}-\mathrm{O}^{-}$fragment, but the replacement of Asp251 acid side chain with amide also leads to substantial active-site differences that significantly affect the disposition of the $\mathrm{Fe}-\mathrm{O}-\mathrm{O}$ structure, as reflected in the downshift of $\mathrm{v}(\mathrm{O}-\mathrm{O})$ vibrational mode. These shifts to lower frequency for the reduced forms of the $\mathrm{D} 251 \mathrm{~N}$ mutant relative to the WT protein are also consistent with the increased stabilization of the lower-frequency conformer of the parent form [4], the $1125 \mathrm{~cm}^{-1}$ component of which was shown to be much more highly populated in the mutant, 
compared to the WT CYP101, at least at $77 \mathrm{~K}$. Although it had been shown previously that at $4^{\circ} \mathrm{C}$, the higher-frequency conformer dominates the spectra for both the WT and D251N mutant,, 45 the results obtained here clearly show that the lower-frequency conformer is substantially populated at $77 \mathrm{~K}$ but only in the case of the mutant. Thus, although the $\mathrm{H}$-bonded conformer is more easily accessed in the case of the mutant, its population is significant only at low temperatures. Such structural changes at cryogenic temperatures have been previously documented in EPR studies of single crystals of oxygenated cobalt myoglobin $\underline{60}$ and in RR studies of deoxy hemoglobin, where significant increases in the frequency of the $\mathrm{v}\left(\mathrm{Fe}-\mathrm{N}_{\text {his }}\right)$ stretching mode, associated with the linkage to the proximal histidine, were reasonably attributed to thermal contraction that stabilizes certain key interactions. $\frac{61}{1}$

Collectively, the data presented in Table 1 provide the first clear opportunity to directly compare experimental vibrational data for these superoxo/peroxo/hydroperoxo heme derivatives in similar environments. In CYP101, upon reduction from [4] to [5a], there is a large shift of $\mathrm{v}(\mathrm{O}-\mathrm{O})$ from $\sim 1135 \mathrm{~cm}^{-1}$, characteristic of bound superoxide, to $\sim 800 \mathrm{~cm}^{-1}$, a frequency indicative of a bound peroxofragment. At the same time, the observed $v(\mathrm{Fe}-\mathrm{O})$ mode shifts to higher frequencies by $\sim 15 \mathrm{~cm}^{-1}$, for example, 537 to $553 \mathrm{~cm}^{-1}$. Protonation to yield the hydroperoxo derivative causes the $\mathrm{v}(\mathrm{O}-\mathrm{O})$ to decrease by $18 \mathrm{~cm}^{-1}$, whereas the $\mathrm{v}(\mathrm{Fe}-\mathrm{O})$ simultaneously increases by $11 \mathrm{~cm}^{-1}$ to $564 \mathrm{~cm}^{-1}$. As can be seen by inspection of Table S1 (Supporting Information), where the results of several computational studies are summarized, the predicted changes in vibrational parameters in proceeding from the parent [4] through the [5a] and [5b] intermediates are generally consistent with those observed here. An exception is the behavior of the $\mathrm{v}(\mathrm{Fe}-\mathrm{O})$ modes in proceeding from [4] to [5a], where strengthening of this bond is evident from the vibrational data, whereas a weakening (longer bond) is predicted from all of the calculations. However, it is particularly satisfying to note that virtually all computational work correctly predicts the anticorrelation, involving increased $\mathrm{Fe}-\mathrm{O}$ and decreased $\mathrm{O}-\mathrm{O}$ bond strengths upon formation of the hydroperoxo intermediate. The weaker $\mathrm{O}-\mathrm{O}$ bond in [5b] can be rationalized in terms of the higher electron density on the dioxygen moiety filling the antibonding $\Pi^{*}$ orbital of hydroperoxide in 
[5b], as compared to unprotonated [5a]. This is consistent with the overall lower spin density on the distal and proximal oxygen atoms in [5b] than in [5a] as suggested on the basis of the proton ENDOR measurements, $\underline{17}$ as well as with the similar predictions of DFT theoretical studies. $\underline{29-34}$

In conclusion, we have documented the vibrational characteristics of the $\mathrm{Fe}-\mathrm{O}-\mathrm{O}$ moiety in the main intermediate states of oxygen activation by the cytochromes P450. By using the D251N mutant of CYP101, we have prepared the oxy-ferrous complex [4] and used cryogenic radiolytic reduction at $77 \mathrm{~K}$ followed by annealing at $185 \mathrm{~K}$ to isolate peroxo-ferric and hydroperoxo-ferric intermediates [5a] and [5b]. By using cryogenic Raman spectroscopy, we have identified for the first time both the $\mathrm{v}(\mathrm{Fe}-\mathrm{O})$ and the $\mathrm{v}(\mathrm{O}-\mathrm{O})$ stretching modes in all three iron-dioxygen intermediates and evaluated experimentally the influence of reduction and protonation on the changes in $\mathrm{Fe}-\mathrm{O}$ and $\mathrm{O}-\mathrm{O}$ bond strength. Reduction of [4] and the concomitant formation of peroxo-ferric complex [5a] result in significant weakening of the $\mathrm{O}-\mathrm{O}$ bond, indicating transition from superoxo to peroxo electronic structure. Further weakening of $\mathrm{O}-\mathrm{O}$ bond is caused by protonation of the distal oxygen atom in [5b], consistent with the predictions of theoretical studies. Contrary, the $\mathrm{Fe}-\mathrm{O}$ bond is becoming stronger during the transition from [4] through $[\mathbf{5 a}]$ and to $[\mathbf{5 b}]$, revealing the presence of the negative correlation between $v(\mathrm{Fe}-\mathrm{O})$ and $\mathrm{v}(\mathrm{O}-\mathrm{O})$. As the first available set of vibrational characteristics of $\mathrm{Fe}-\mathrm{O}-\mathrm{O}$ intermediates, our data provide further insight into the mechanism of oxygen activation in heme enzymes, as well as the convenient benchmark for the refinement of the detailed quantum chemical calculations.

\section{Acknowledgment}

We thank Dr. Na Ke for the help in constructing the plasmid with PT7-P450 His gene, Dr. S. Toshkov for irradiation of the samples at the ${ }^{60} \mathrm{Co}$ source, and Dr. M. Nilges for the help in EPR measurements. This work was supported by National Institutes of Health Grants GM 31756 to S.G.S and DK 35153 to J.R.K. 
NOT THE PUBLISHED VERSION; this is the author's final, peer-reviewed manuscript. The published version may be accessed by following the link in the citation at the bottom of the page.

\section{Supporting Information}

One figure representing RR spectra of irradiated and annealed at different temperatures samples and one table with the calculated parameters of $\mathrm{Fe}-\mathrm{O}-\mathrm{O}$ bonds in $[\mathbf{4}],[5 \mathbf{a}]$, and [5b] taken from the literature. This material is available free of charge via the Internet at http://pubs.acs.org.

\section{Resonance Raman Characterization of the Peroxo and Hydroperoxo Intermediates in Cytochrome P450}


NOT THE PUBLISHED VERSION; this is the author's final, peer-reviewed manuscript. The published version may be accessed by following the link in the citation at the bottom of the page.

\title{
Resonance Raman Characterization of the Peroxo and Hydroperoxo
}

\section{Intermediates in Cytochrome P450}

\author{
Supporting Information \\ llia G. Denisov', Piotr J. Mak², Thomas M. Makris', Stephen G. Sligar ${ }^{1,3,4}$, James R. Kincaid ${ }^{2}$ \\ Department of Biochemistry'. Chemistry ${ }^{4}$, and College of Medicine ${ }^{4}$, University of Illinois, \\ Urbana, IL 61801, and Department of Chemistry'2, Marquette University, Milwaukee, WI 53233
}

Journal of Physical Chemistry A, Vol 112, No. 50 (December 18, 2008): pg. 13172-13179. DOI. This article is @ American Chemical Society and permission has been granted for this version to appear in e-Publications@Marquette. American Chemical Society does not grant permission for this article to be further copied/distributed or hosted elsewhere without the express permission from American Chemical Society. 
NOT THE PUBLISHED VERSION; this is the author's final, peer-reviewed manuscript. The published version may be accessed by following the link in the citation at the bottom of the page.

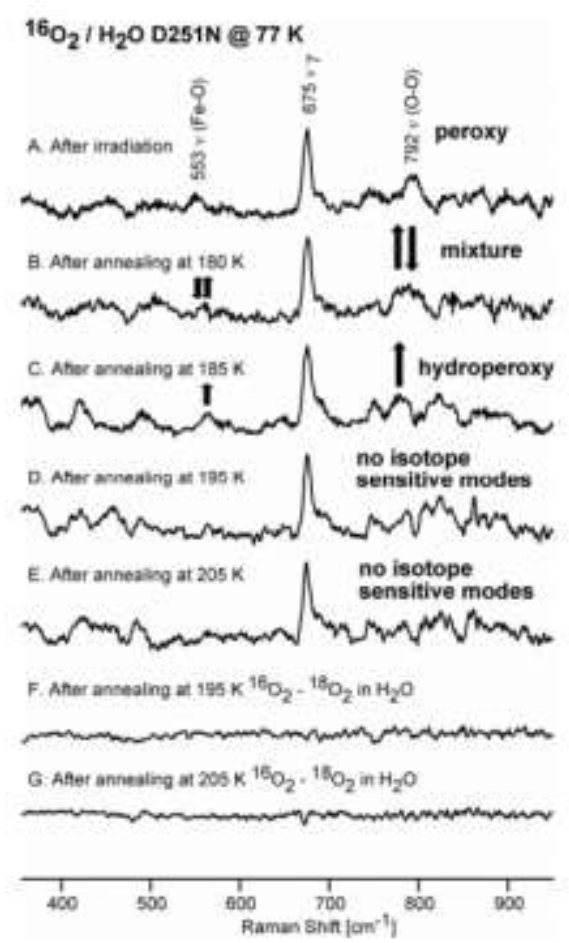

Figure SI. The resonance Raman spectra of irradiated and annealed at different temperature samples of D251N CYP101 in $\mathrm{H}_{2} \mathrm{O}$ buffer: immediately after irradiation (A); after annealing at $180 \mathrm{~K}(\mathrm{~B})$; after annealing at $185 \mathrm{~K}(\mathrm{C})$; after annealing at $195 \mathrm{~K}$ (D), and after annealing at 205 $\mathrm{K}$ (E). Two bottom traces shows difference spectra between ${ }^{16} \mathrm{O}_{2}{ }^{18} \mathrm{O}_{2}$ in $\mathrm{H}_{2} \mathrm{O}$ of the samples annealed at $195 \mathrm{~K}$ (F) and at $205 \mathrm{~K}$ (G) (excitation at 442, temperature $77 \mathrm{~K}$ ).

Journal of Physical Chemistry A, Vol 112, No. 50 (December 18, 2008): pg. 13172-13179. DOI. This article is (C) American Chemical Society and permission has been granted for this version to appear in e-Publications@Marquette. American Chemical Society does not grant permission for this article to be further copied/distributed or hosted elsewhere without the express permission from American Chemical Society. 
NOT THE PUBLISHED VERSION; this is the author's final, peer-reviewed manuscript. The published version may be accessed by following the link in the citation at the bottom of the page.

Table S1. Calculated parameters of $\mathrm{Fe}-\mathrm{O}-\mathrm{O}$ in [4]. [5a]. and [5b]

\begin{tabular}{|l|l|l|l|l|}
\hline System & Fe-O, A & O-O, A & Fe-O-O. deg & Ref \\
\hline$[\mathbf{4}]$ & $1.82-2.0$ & $1.31-1.37$ & & \\
{$[\mathbf{5 a}]$} & 1.99 & 1.41 & & \\
{$[\mathbf{5 b}]$} & $1.86-1.87(1.82)$ & $1.52(1.45)$ & & $+2)$ \\
\hline$[\mathbf{4}]$ & 1.94 & 1.32 & & 7 \\
{$[\mathbf{5 b}]$} & 1.80 & 1.44 & & \\
\hline$[\mathbf{4}]$ & 1.95 & 1.31 & 119 & \\
{$[\mathbf{5 a}]$} & 1.99 & 1.33 & 121 & \\
{$[\mathbf{5 b}]$} & 1.88 & 1.46 & 117 & \\
\hline$[\mathbf{4}]$ & 1.81 & 1.29 & & \\
{$[\mathbf{5 a}]$} & 1.92 & 1.31 & & \\
{$[\mathbf{5 b}$} & 1.85 & 1.45 & & \\
\hline$[\mathbf{4}]$ & 1.82 & 1.31 & & \\
{$[\mathbf{5 a}]$} & 1.95 & 1.33 & & \\
{$[\mathbf{5 b}$} & 1.89 & 1.46 & & \\
\hline
\end{tabular}

References

(1) Shaik, S.; Kumar, D.; de Visser, S. P.; Altun, A.; Thiel, W. Chem. Rev. 2005, 105, 2279-2328.

(2) Kumar, D,; Hirao, H.; De Visser, S. P ; Zheng, J; Wang, D; Thiel, W.; Shaik, S. J. Phys, Chem. B 2005, 109, 19946-19951.

(3) Guallar, V.; Friesner, R. A. J. Ant. Chem. Soc. 2004, 126, 8501-8508.

(4) Rydberg. P.; Sigfridsson, E, Ryde, U. J. Biol. Jnorg. Chem. 2004, 9. 203-223

(5) Hackett, J. C. Computational Investigations of Cytochrome P450 Aromatase

Catalysis and Biological Evaluation of Isoflavone Inhibitors. Ph.D. Thesis, Ohio State University, 2004.

(6) Loew, G. H. Harris, D. L. Chem, Rev, 2000, 100, 407-419.

\section{References}

1 Makris, T. M.; Davydov, R.; Denisov, I. G.; Hoffman, B. M.; Sligar, S. G. Drug Metab. Rev. 200234691708

2 Makris, T. M.; Denisov, I. G.; Schlichting, I.; Sligar, S. G. Activation of Molecular Oxygen by Cytochrome P450. In Cytochrome P450:

Journal of Physical Chemistry A, Vol 112, No. 50 (December 18, 2008): pg. 13172-13179. DOI. This article is @ American Chemical Society and permission has been granted for this version to appear in e-Publications@Marquette. American Chemical Society does not grant permission for this article to be further copied/distributed or hosted elsewhere without the express permission from American Chemical Society. 
NOT THE PUBLISHED VERSION; this is the author's final, peer-reviewed manuscript. The published version may be accessed by following the link in the citation at the bottom of the page.

Structure, Function, Genetics. 3rd ed.; Ortiz de Montellano, P. R., Ed.; Kluwer Academic/Plenum Publishers: New York, 2005; pp 149- 182.

3 Denisov, I. G.; Makris, T. M.; Sligar, S. G.; Schlichting, I. Chem. Rev. 2005 10522532277

${ }^{4}$ Que, L., Jr.; Ho, R. Y. N. Chem. Rev. 19969626072624

5 Bukowski, M. R.; Halfen, H. L.; van den Berg, T. A.; Halfen, J. A.; Que, L. Angew. Chemie, Int. Ed. 200544584587

6 Decker, A.; Solomon, E. I. Curr. Opin. Chem. Biol. 20059152163

7 Neidig, M. L.; Solomon, E. I. Chem. Commun. 200558435863

8 Bakac, A. Adv. Inorg. Chem. 200455159

9 Bakac, A. Coord. Chem. Rev. 200625020462058

10 Neese, F.; Zaleski, J. M.; Zaleski, K. L.; Solomon, E. I. J. Am. Chem. Soc. 20001221170311724

11 Roelfes, G.; Vrajmasu, V.; Chen, K.; Ho, R. Y. N.; Rohde, J.-U.; Zondervan, C.; la Crois, R. M.; Schudde, E. P.; Lutz, M.; Spek, A. L.; Hage, R.; Feringa, B. L.; Munck, E.; Que, L. Inorg. Chem. 20034226392653

12 Solomon, E. I.; Decker, A.; Lehnert, N. Proc. Natl. Acad. Sci. U.S.A. 2003 10035893594

13 Solomon, E. I.; Brunold, T. C.; Davis, M. I.; Kemsley, J. N.; Lee, S.-K.; Lehnert, N.; Neese, F.; Skulan, A. J.; Yang, Y.-S.; Zhou, J. Chem. Rev. 2000100235349

14 Costas, M.; Mehn, M. P.; Jensen, M. P.; Que, L. Chem. Rev. 2004104939 986

15 Girerd, J.-J.; Banse, F.; Simaan, A. J. Struct. Bonding (Berlin) 200097145 177

16 Davydov, R. M.; Yoshida, T.; Ikeda-Saito, M.; Hoffman, B. M. J. Am. Chem. Soc. 19991211065610657

17 Davydov, R.; Makris, T. M.; Kofman, V.; Werst, D. E.; Sligar, S. G.; Hoffman, B. M. J. Am. Chem. Soc. 200112314031415

18 Davydov, R.; Macdonald, I. D. G.; Makris, T. M.; Sligar, S. G.; Hoffman, B. M. J. Am. Chem. Soc. 19991211065410655

19 Davydov, R.; Ledbetter-Rogers, A.; Martasek, P.; Larukhin, M. ; Sono, M.; Dawson, J. H.; Masters, B. S.; Hoffman, B. M. Biochemistry 200241 1037510381

20 Davydov, R.; Kofman, V.; Fujii, H.; Yoshida, T.; Ikeda-Saito, M.; Hoffman, B. M. J. Am. Chem. Soc. 200212417981808

$\underline{21}$ Davydov, R.; Kofman, V.; Nocek, J. M.; Noble, R. W.; Hui, H.; Hoffman, B. M. Biochemistry 20044363306338

22 Davydov, R.; Perera, R.; Jin, S.; Yang, T. C.; Bryson, T. A.; Sono, M.; Dawson, J. H.; Hoffman, B. M. J. Am. Chem. Soc. 200512714031413

23 Kim, S. H.; Yang, T.-C.; Perera, R.; Jin, S.; Bryson, T. A.; Sono, M.; Davydov, R.; Dawson, J. H.; Hoffman, B. M. Dalton Trans. 20053464 3469

Journal of Physical Chemistry A, Vol 112, No. 50 (December 18, 2008): pg. 13172-13179. DOI. This article is (C) American Chemical Society and permission has been granted for this version to appear in e-Publications@Marquette. American Chemical Society does not grant permission for this article to be further copied/distributed or hosted elsewhere without the express permission from American Chemical Society. 
24 Garcia-Serres, R.; Davydov, R. M.; Matsui, T.; Ikeda-Saito, M.; Hoffman, B. M.; Huynh, B. H. J. Am. Chem. Soc. 200712914021412

25 Beitlich, T.; Kuhnel, K.; Schulze-Briese, C.; Shoeman, R. L.; Schlichting, I. J. Synchrotron Radiat. 2007141123

26 Kuhnel, K.; Derat, E.; Terner, J.; Shaik, S.; Schlichting, I. Proc. Natl. Acad. Sci. U.S.A. 200710499104

27 Unno, M.; Chen, H.; Kusama, S.; Shaik, S.; Ikeda-Saito, M. J. Am. Chem. Soc. 20071291339413395

28 Hersleth, H. P.; Hsiao, Y. W.; Ryde, U.; Gorbitz, C. H.; Andersson, K. K. Biochem. J. 2008, 412, 257- 264.

$\underline{29}$ Loew, G. H.; Harris, D. L. Chem. Rev. 2000100407419

30 Ogliaro, F.; de Visser Sam, P.; Cohen, S.; Sharma Pankaz, K.; Shaik, S. J. Am. Chem. Soc. 200212428062817

31 Rydberg, P.; Sigfridsson, E.; Ryde, U. J. Biol. Inorg. Chem. 20049203223

32 Shaik, S.; Kumar, D.; de Visser, S. P.; Altun, A.; Thiel, W. Chem. Rev. 200510522792328

33 Kumar, D.; Hirao, H.; De Visser, S. P.; Zheng, J.; Wang, D.; Thiel, W.; Shaik, S. J. Phys. Chem. B 20051091994619951

34 Hackett, J. C.; Brueggemeier, R. W.; Hadad, C. M. J. Am. Chem. Soc. 2005 12752245237

35 Gerber, N. C.; Sligar, S. G. J. Am. Chem. Soc. 199211487428743

36 Gerber, N. C.; Sligar, S. G. J. Biol. Chem. 199426942604266

37 Vidakovic, M.; Sligar, S. G.; Li, H.; Poulos, T. L. Biochemistry 1998379211 9219

38 Schlichting, I.; Berendzen, J.; Chu, K.; Stock, A. M.; Maves, S. A.; Benson, D. E.; Sweet, R. M.; Ringe, D.; Petsko, G. A.; Sligar, S. G. Science 200028716151622

39 Taraphder, S.; Hummer, G. J. Am. Chem. Soc. 200312539313940

40 Makris, T. M.; von Koenig, K.; Schlichting, I.; Sligar, S. G. Biochemistry 2007461412914140

41 Ibrahim, M.; Denisov, I. G.; Makris, T. M.; Kincaid, J. R.; Sligar, S. G. J. Am. Chem. Soc. 20031251371413718

42 Mak, P. J.; Denisov, I. G.; Victoria, D.; Makris, T. M.; Deng, T.; Sligar, S. G.; Kincaid, J. R. J. Am. Chem. Soc. 200712963826383

43 Denisov, I. G.; Makris, T. M.; Sligar, S. G. J. Biol. Chem. 200127611648 11652

44 Denisov, I. G.; Makris, T. M.; Sligar, S. G. Methods Enzymol. 2002357103 115

45 Sjodin, T.; Christian, J. F.; Macdonald, I. D. G.; Davydov, R.; Unno, M.; Sligar, S. G.; Hoffman, B. M.; Champion, P. M. Biochemistry 200140 68526859

$\underline{46}$ Bajdor, K.; Kincaid, J. R.; Nakamoto, K. J. Am. Chem. Soc. 19841067741 7747

Journal of Physical Chemistry A, Vol 112, No. 50 (December 18, 2008): pg. 13172-13179. DOI. This article is @ American Chemical Society and permission has been granted for this version to appear in e-Publications@Marquette. American Chemical Society does not grant permission for this article to be further copied/distributed or hosted elsewhere without the express permission from American Chemical Society. 
NOT THE PUBLISHED VERSION; this is the author's final, peer-reviewed manuscript. The published version may be accessed by following the link in the citation at the bottom of the page.

47 Li, D.; Kabir, M.; Stuehr, D. J.; Rousseau, D. L.; Yeh, S. R. J. Am. Chem. Soc. 200712969436951

48 Kitagawa, T.; Ondrias, M. R.; Rousseau, D. L.; Ikeda-Saito, M.; Yonetani, T. Nature 1982298869871

49 Bruha, A.; Kincaid, J. R. J. Am. Chem. Soc. 198811060066014

50 Proniewicz, L. M.; Kincaid, J. R. J. Am. Chem. Soc. 1990112675681

$\underline{51}$ Proniewicz, L. M.; Kincaid, J. R. Coord. Chem. Rev. 199716181127

52 Tani, F.; Matsu-ura, M.; Nakayama, S.; Ichimura, M.; Nakamura, N.; Naruta, Y. J. Am. Chem. Soc. 200112311331142

53 Macdonald, I. D. G.; Sligar, S. G.; Christian, J. F.; Unno, M.; Champion, P. M. J. Am. Chem. Soc. 1999121376380

54 Hirota, S.; Ogura, T.; Appelman, E. H.; Shinzawa-Itoh, K.; Yoshikawa, S. ; Kitagawa, T. J. Am. Chem. Soc. 19941161056410570

55 Das, T. K.; Couture, M.; Ouellet, Y.; Guertin, M.; Rousseau, D. L. Proc. Natl. Acad. Sci. U.S.A. 200198479484

56 Jeyarajah, S.; Proniewicz, L. M.; Bronder, H.; Kincaid, J. R. J. Biol. Chem. 19942693104731050

57 Rajani, C.; Kincaid, J. R.; Petering, D. H. J. Am. Chem. Soc. 20041263829 3836

$\underline{58}$ von Koenig, K.; Schlichting, I. Cytochromes P450 - structural basis for binding and catalysis. In Ubiquitous Roles of Cytochrome P450 Proteins; Siegel, A.; Siegel, H.; Siegel, R. K. O., Eds.; Wiley and Sons: New York, 2007; Vol. 3; pp 235- 265.

$\underline{59}$ Nagano, S.; Poulos, T. L. J. Biol. Chem. 20052803165931663

$\underline{60}$ Hori, H. ; Ikeda-Saito, M.; Yonetani, T. Nature 1980288501502

$\underline{61}$ Rousseau, D. L.; Friedman, J. M. Transient and cryogenic studies of photodissociated hemoglobin and myoglobin. In Biological Applications of Raman Spectroscopy; Spiro, T. G., Ed.; Wiley and Sons: New York, 1988; Vol. 3; pp 133- 216

+ Part of the "Sason S. Shaik Festschrift".

* Corresponding authors. E-mail: james.kincaid@mu.edu. Tel: 414-288-3539. Fax: 414-288-7066 (J.R.K.). E-mail: s-sligar@uiuc.edu (S.G.S.). Tel: 217244-7395. Fax: 217-265-4073., ₹ Department of Biochemistry, University of Illinois.

, § Department Chemistry, University of Illinois., \|| College of Medicine, University of Illinois., $\perp$ Department of Chemistry, Marquette University. This article is part of the $\underline{A}$ : Sason Shaik Festschrift special issue.

Journal of Physical Chemistry A, Vol 112, No. 50 (December 18, 2008): pg. 13172-13179. DOI. This article is @ American Chemical Society and permission has been granted for this version to appear in e-Publications@Marquette. American Chemical Society does not grant permission for this article to be further copied/distributed or hosted elsewhere without the express permission from American Chemical Society. 